\title{
SCIENCE IN THE PROVINCES
}





\section{SCIENCE IN THE PROVINCES}

Scientific Communities and Provincial Leadership in France, 1860-1930

MARY JO NYE 
University of California Press

Berkeley and Los Angeles, California

University of California Press, Ltd.

London, England

Copyright $₫ 1986$ by The Regents of the University of California

\section{Library of Congress Cataloging in Publication Data}

Nye, Mary Jo.

Science in the provinces.

Includes index.

1. Science-France-History. I. Title.

Q127.F8N94 $1985 \quad 306^{\prime} .45^{\prime} 0944 \quad 85-8503$

ISBN 0-520-05561-6

Printed in the United States of America

123456789 
FOR BOB AND LESLEY 
